\title{
The Spectrum of Molecular Alterations in the Evolution of Chronic Myelocytic Leukemia
}

\author{
Harish Ahuja, " Menashe Bar-Eli,* Zalmen Arlin, ${ }^{*}$ Suresh Advani,' Steven L. Allen," \\ John Goldman," David Snyder,"* Andras Foti," and Martin Cline* \\ *UCLA Department of Medicine and Jonsson Cancer Center, Division of Hematotology/Oncology, 11-662 Factor Building, Los Angeles, \\ California 90024; ${ }^{\ddagger}$ New York Medical College, Valhalla, New York; ${ }^{8}$ North Shore University Hospital, Cornell University Medical \\ Center, Manhasset, New York; 'TATA Memorial Hospital, Bombay, India; "Hammersmith Hospital, Royal Post Graduate \\ Medical School, London; and ${ }^{* *}$ City of Hope Medical Center, Duarte, California 91010
}

\begin{abstract}
DNA from 135 patients with chronic myelogenous leukemia (CML) at various clinical stages and Philadelphia $\left(\mathbf{P h}^{\mathbf{1}}\right)$ chromosome positive acute lymphoblastic leukemia was investigated for alterations in a variety of proto-oncogenes which have been implicated in the evolution of CML from its chronic phase to blast crisis. The most common genetic change found in the evolution of typical $\mathrm{Ph}^{1}$ chromosome positive CML to blast crisis was an alteration of the p53 gene involving either a rearrangement, a deletion, or a point mutation in the coding sequence of the gene. Alterations of the p53 gene were found in the myeloid and the rare megakaryocytic variant of blast crisis but were absent in the lymphoid leukemic transformants. Gross structural alterations were seen in 11 of $54(20 \%)$ of myeloid or unknown phenotypes of blast crisis and in only 1 of 44 chronic phase cases. Eight examples of mutations in the open reading frame of the p53 gene at codons $49,53,60,140,202,204,238$, and 239 were observed in blast crisis patients. Mutations in the $N-R A S$ gene were rare in typical blast crisis ( 2 of 27 cases) but were found in megakaryocytic and $\mathrm{Ph}^{1}$ negative myeloid blast crisis. We concluded that heterogeneous alterations in the p53 gene and occasionally in the $N-R A S$ genes accompany the evolution of chronic phase CML to blast crisis. (J. Clin. Invest. 1991. 87:2042-2047.) Key words: p53 • N-RAS • CML • blast crisis • mutations
\end{abstract}

\section{Introduction}

It was 30 years ago that Nowell and Hungerford described the Philadelphia $\left(\mathrm{Ph}^{1}\right)^{1}$ chromosome in the leukemic leukocytes of patients with chronic myelocytic leukemia (CML) and thus identified the first cancer-associated distinctive chromosomal anomaly (1). Although initially thought to be a deletion of chromosome $22(22 \mathrm{q}-)$, it was shown to actually represent a reciprocal translocation involving the long arm of chromo-

Address correspondence and reprint requests to Dr. Harish Ahuja, UCLA Department of Medicine and Jonsson Cancer Center, Division of Hematology/Oncology, 11-662 Factor Building, 10833 Le Conte Avenue, Los Angeles, CA 90024.

Received for publication 17 July 1990 and in revised form 24 January 1991.

1. Abbreviations used in this paper: ALL, acute lymphoblastic leukemia; CML, chronic myelogenous leukemia; $\mathbf{P h}^{1}$, Philadelphia.

J. Clin. Invest.

(c) The American Society for Clinical Investigation, Inc.

0021-9738/91/06/2042/06 $\$ 2.00$

Volume 87, June 1991, 2042-2047 somes 9 and 22 (2). In the mid-1980's several groups of investigators established that it was the fusion of the $c-A B L$ proto-oncogene from chromosome 9 and the $B C R$ locus from chromosome 22 which was the critical element in the $\mathrm{Ph}^{1}$ chromosomal anomaly (3-8). Subsequently, similar fusions were found in $\mathrm{Ph}^{1}$ positive $\left(\mathrm{Ph}^{+}\right)$cases of acute lymphoblastic leukemia (ALL) and in occasional $\mathrm{Ph}^{1}$ negative $\left(\mathrm{Ph}^{-}\right) \mathrm{CML}$ cases (9-11). Many studies established the pathogenetic signifcance of the fused $A B L$ gene in the chronic phase of CML (12, 13); however, a variety of evidence suggested that rearranged $A B L$ was not involved in the subsequent evolution of CML $(14,15)$. CML almost always evolves from a chronic, relatively indolent disease to a more aggressive leukemia whose progressive stages are accelerated phase and blast crisis (16). Furthermore, the blast cells of the aggressive phases may be of several types, most commonly myeloid, less commonly lymphoid, and rarely other phenotypes, suggesting that different molecular events induce different forms of disease. These molecular events eluded identification for several years, although there were occasional suggestions that $R A S$ genes or sometimes the $c-M Y C$ gene could be the molecular culprit $(17,18)$. Recently, we observed that structural alterations of the p 53 gene occur in $\sim 25 \%$ of blast crisis cases, especially those with a myeloid phenotype, but were very rare during the chronic phase, suggesting that the p53 gene might be involved in evolution of some cases of blast crisis $(19,20)$. Subsequently, two other reports, one from Israel (21) and one from Texas (22), also described structural alterations in the p53 gene in the blast crisis of CML. These findings together with the recent subclassification of p53 as a tumor suppressor gene (23), the presence of nonrandom changes involving chromosome 17 , the site of the p53 gene, in about a third of cases of myeloid blast crisis (24), and the identification of point mutations in other tumors harboring allelic deletions of $17 p(25-27)$, all suggest that more subtle structural abnormalities such as point mutations may be responsible for disease evolution in patients not showing gross structural alterations of the p53 gene. In order to explore this possibility and to extend our observations to other phenotypes of blast crisis and related diseases such as $\mathrm{Ph}^{+} \mathrm{ALL}$, we analyzed these cases for both gross and subtle alterations in the p53 gene and in other genes that have been implicated in hematological malignancies in man. The analysis constitutes the substance of this report.

\section{Methods}

Bone marrow or peripheral blood samples were collected at the collaborating institutions after obtaining informed consent of the patients and were kept frozen at $-70^{\circ} \mathrm{C}$. The diagnosis of $\mathrm{CML}$ was based on standard clinical and hematologic criteria. All cases in which karyotype 
analysis was unavailable or reported as $\mathrm{Ph}^{-}$were checked for $B C R$ locus rearrangement by Southern blotting. For the blast crisis samples, markers such as myeloperoxidase, Sudan black, periodic acid Schiff reagent, nonspecific esterase with fluoride sensitivity, and acid phosphatase were analyzed. Additional determinants of phenotype included the reactivity of the blasts to a panel of lineage-specific monoclonal antibodies and the activity of terminal deoxynucleotidyltransferase determined by indirect immunofluorescence.

DNA and RNA were isolated from fresh or frozen leukemic cells and analyzed by Southern and Northern blotting as described $(28,29)$. For Northern blotting, the signal of $\beta$-Actin mRNA served as a control. DNA digested with EcoRI, BamHI, HindIII, or BglII was separated by electrophoresis on $0.8 \%$ agarose gels, transferred to coated nylon filters, hybridized to nick-translated ${ }^{32} \mathrm{P}$-labeled probes, and autoradiographed with Kodak intensifying screens. The strategy used in Southern blotting analysis of the p53 gene involved hybridization with a cDNA probe encompassing all the known exons of the gene (30)(Fig. $1 C$ ) and restriction of DNA with EcoRI which cleaves the gene into a few fragments (31). A variety of other p53 probes and enzymes were used to define deletions and rearrangements as previously described (19). Where loss of the p 53 gene was detected, hybridization with other chromosome 17 probes (c-ERBB2 and myeloperoxidase [MPO]) was also used to exclude loss of the whole chromosome.

Southern blots of restriction digests of DNA from leukemic cells were also hybridized with probes for $c-M Y C, c-M Y B, c-F M S, N-R A S$, $H$-RAS, K-RAS, c-FES, c-FOS, BCR, c-ERBB2 (NEU), and MPO as described (32).

Fragments encompassing coding exons $2-11$ of the p53 gene and the first and second exons of the $N-R A S, K-R A S$, and $H-R A S$ genes were amplified by the PCR (33) using synthetic primers of 20 bases spanning the $5^{\prime}$ and $3^{\prime}$ ends of the target sequence and sequenced. The PCR was performed for 30 cycles using Thermus aquaticus DNA polymerase with the following periods: $95^{\circ} \mathrm{C}(1 \mathrm{~min}), 55^{\circ} \mathrm{C}(0.5 \mathrm{~min})$, and $72^{\circ} \mathrm{C}(1.5 \mathrm{~min})$. The amplified fragments were electrophoresed on $3 \%$ Nusieve agarose, electroeluted, purified on Elutip D (Schleicher \& Schuell, Inc., Keene, NH), and ethanol precipitated. Sequencing was as described (34) using Sequenase, version 2.0 (United States Biochemical Corp., Cleveland, $\mathrm{OH}$ ), a third primer from the sense or antisense strands labeled with T4 kinase, and $\gamma^{32} \mathrm{P}$ ATP. The dried $10 \%$ polyacrylamide gel was exposed to film overnight without screen intensification. Samples showing mutations were subjected to repeated analyses and were usually sequenced in both directions. Over 250 frozen normal and tumor samples served as controls in the analysis of CML samples for gross structural alterations of p53 $(32,35)$. Correlation analysis was done by the $x^{2}$ method. Studies with recombinant DNA molecules conformed to the standards outlined by the Recombinant DNA Research Guidelines of the National Institutes of Health (July 1976).

\section{Results}

We studied a total of 135 cases including $53 \mathrm{Ph}^{+}$and $2 \mathrm{Ph}^{-}$ chronic phase, $\mathrm{CML}, 17 \mathrm{Ph}^{+}$accelerated phase, acute myelogenous leukemia, $53 \mathrm{Ph}^{+}$and $2 \mathrm{Ph}^{-}$blast crisis, $6 \mathrm{Ph}^{+} \mathrm{ALL}$, and 2 extramedullary blast crisis for abnormalities of p53 gene structure and expression. Of this number, we have previously reported the results of Southern blotting on 35 cases of blast crisis and 38 cases of chronic phase of $\mathrm{Ph}^{+} \mathrm{CML}$ (19).

Southern blotting. Three types of alterations of the $\mathrm{p} 53$ gene were observed: deletion, gross rearrangements (Fig. $1 B$ ), and alterations of the EcoRI restriction pattern without gross rearrangement on analysis with other restriction enzymes (Fig. 1 $A$ ). Although the latter alteration could have resulted from an RFLP, we believe this is unlikely because a similar hybridization pattern was not observed in $\sim 250$ normal and tumor samples unrelated to CML (19). Consequently, we have interpreted this as an acquired change resulting from a small inser-
$\mathbf{A}$
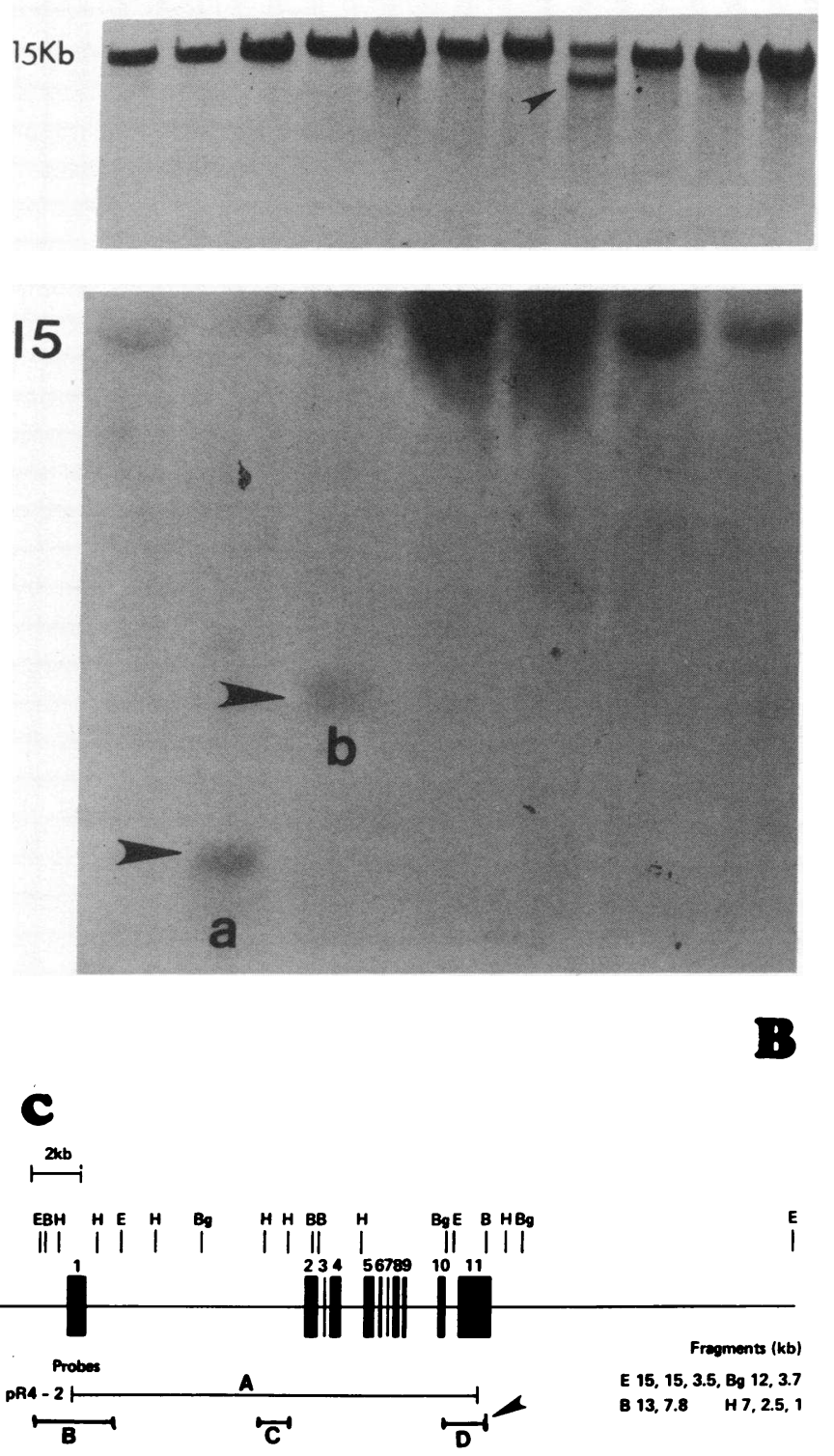

Figure 1. (A) Southern blots of EcoRI-digested DNA from CML blast crisis cases hybridized with a p53 cDNA probe. One sample (arrow) shows a novel band in addition to the germline $15-\mathrm{kb}$ band. $(B)$ Another Southern blot of EcoRI-digested DNA hybridized with a p53 exon 11 probe. Arrows indicate novel bands in 2 myeloid blast crisis samples. $(C)$ The p53 gene after Lamb and Crawford (31) showing 11 exons and the hybridization probes used in the analysis. Probe $A$ was used for panel $A$ and probe $D$ (arrow) for panel $B$. The sites of restriction and anticipated fragment sizes are shown for $\operatorname{EcoRI}(E)$, BamHI $(B)$, BglII $(B g)$, and HindIII $(H)$.

tion or mutation in the p53 gene. Structural alterations of the p53 gene were rare in typical chronic phase CML and were observed only once in $44 \mathrm{Ph}^{+}$cases. Southern blotting abnormalities of the p 53 gene were observed more frequently in the accelerated and blast crisis phases of the disease, and were also more frequent in diseases of nonlymphoid phenotype. No gross structural alterations of $\mathrm{p} 53$ were seen in 7 lymphoid blast crisis or $6 \mathrm{Ph}^{+}$ALL cases. Among $54 \mathrm{Ph}^{+}$accelerated and blast crisis cases, abnormal Southern blots of the p53 gene were ob- 
served in 9 of $43(21 \%)$ myeloid and 2 of 11 (18\%) unknown phenotype, respectively. This difference in frequency of gross structural abnormalities of the $\mathrm{p} 53$ gene between chronic phase and blast crisis of nonlymphoid phenotype was statistically significant $(P<0.01)$.

In this study, alterations in the p53 structure were observed in 2 cases early in the evolution of blast crisis when there were fewer than $10 \%$ blasts in the leukemic populations. A pertinent negative finding was the lack of detectable alteration in the structure of 9 other proto-oncogenes in 11 blast crisis patients including 3 with p53 gene rearrangements (see Methods).

We had previously studied 38 of the 57 acute phase $\mathrm{Ph}^{+}$ CML patients reported here and had observed a somewhat higher incidence $(24 \%)$ of gross structural alterations of the p53 gene in disease of myeloid phenotype (19). Those patients initially reported were almost all Indians from Bombay, whereas the series reported here were about equally divided between Western and Asian patients. In general, the Indian patients had more advance disease with higher white cell counts $(140,000$ $+60,000$ vs. $62,000+36,000 ; P<0.05$ ) at the time of study. However, the differences in the incidence of p53 gene abnormalities were not statistically different between the current study and the earlier smaller study.

Mutations of the p53 and N-RAS genes. Mutations of the p53 gene have not been previously reported in CML and related disorders. We initially selected 8 blast crisis samples for analysis of the entire coding sequence and the promoter area of the p 53 gene and identified mutatios in 3 cases ( $37 \%$ incidence) in the region between exons 4 and 7. The promoter and exons 8 and 9 were sequenced in an additional 29 blast crisis cases and no mutations were found. We, therefore, concentrated on exons 4 through 7 for detailed sequencing with the realization that rare mutations of the p53 gene may occur outside this region. The results were as follows. No mutations were observed in 14 chronic phase cases or in 4 lymphoid blast crisis. We observed mutations in 8 of 25 cases of CML blast crisis of myeloid phenotype (32\% incidence; see Table I and Figs. 2-6).

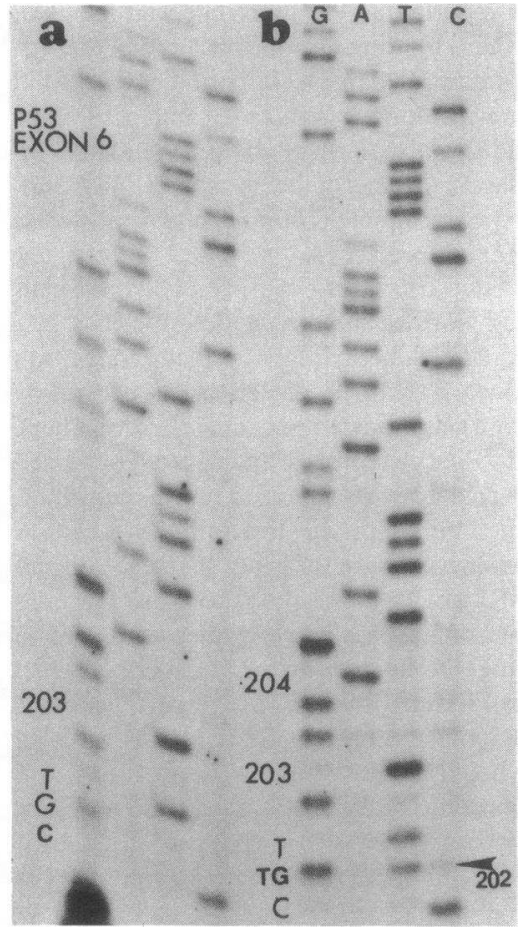

Figure 2. A mutation in codon 202 of the $\mathrm{p} 53$ gene in leukocytes from a case of megakaryocytic blastic transformation (No. 1089). The normal CGT pattern of this codon is shown in the left panel. In the right panel we can see both a $\mathrm{G}$ and a $\mathrm{T}$ (arrow) at this position, indicating both mutant and normal alleles in the patient's leukocytes.

In $\mathrm{Ph}^{+}$accelerated and blast crisis cases mutations in p53 were found in exons 4, 6, and 7 at codons 49, 53, 60, 202, 204, 238, and 239 (Figs. 2-4, 6). The mutations in exon 6 and 7 occurred in a region of the gene that is phylogenetically conserved and within a region which when altered can activate the murine p 53 gene (23). The mutations in codons 49,53 , and 60 occurred in a region not previously described as containing mutations in human cancers (25-27). A mutation at codon 140 of the p53 gene was also found in an unusual case of extramedullary presentation of $\mathrm{a}^{-}$myeloid leukemia (a chloroma or granulocytic sarcoma) (Fig. 5). Conventional histology and

Table I. Mutations in the p53 and N-RAS Genes

\begin{tabular}{|c|c|c|c|c|c|}
\hline Case & Phase & Phenotype & Gene & Mutation & Comment \\
\hline 1235 & Accelerated & Myeloid & p53 & codon 49 Asp $\rightarrow$ His & WBC 35,$000 ; 10 \%$ blasts \\
\hline 1245 & Blast crisis & Myeloid & p53 & codon 53 Trp $\rightarrow$ Cys & No p53 transcripts WBC 108,$000 ; 20 \%$ blasts \\
\hline 1086 & Blast crisis & Myeloid & p53 & codon 60 Pro $\rightarrow$ Ser & $65 \%$ blasts \\
\hline 972 & Extramedullary & Myeloid & p53 & codon 140 Cys $\rightarrow$ Tyr & $\mathrm{Ph}^{1}(-)$ \\
\hline 1089 & Blast crisis & Megakaryocytic & p53 & codon $202 \mathrm{Arg} \rightarrow \mathrm{Leu}$ & WBC 45,$000 ; 28 \%$ blasts \\
\hline 1324 & Blast crisis & Unknown & p53 & codon 204 Glu $\rightarrow$ Gly & Isochromosome $17 \mathrm{q}$ (10\% blasts) \\
\hline 1326 & Blast crisis & Myeloid & p53 & codon 238 Cys $\rightarrow$ Tyr & Blasts $85 \%$ t(17; 22) (p13; q11) (100\%) \\
\hline 1443 & Blast crisis & Myeloid & p53 & codon 239 Asn $\rightarrow$ Ser & Blasts $42 \%$, del $17 p$ \\
\hline 901 & Blast crisis & Myeloid & $N-R A S$ & codon 13 Gly $\rightarrow$ Val & WBC 174,$000 ; 24 \%$ blasts \\
\hline 749 & Blast crisis & Megakaryocytic & $N-R A S$ & codon 13 Gly $\rightarrow$ Ala & WBC 57,$000 ; 87 \%$ blasts \\
\hline 1233 & Blast crisis & Myeloid & $N-R A S$ & codon 12 Gly $\rightarrow$ Asp & $\mathrm{Ph}^{1}(-)$ blasts $>20 \%$ \\
\hline 1085 & Blast crisis & Myeloid & $N-R A S$ & codon 13 Gly $\rightarrow$ Ala & WBC 150,000 ; blasts $30 \%$ \\
\hline
\end{tabular}

WBC, white blood cells. 

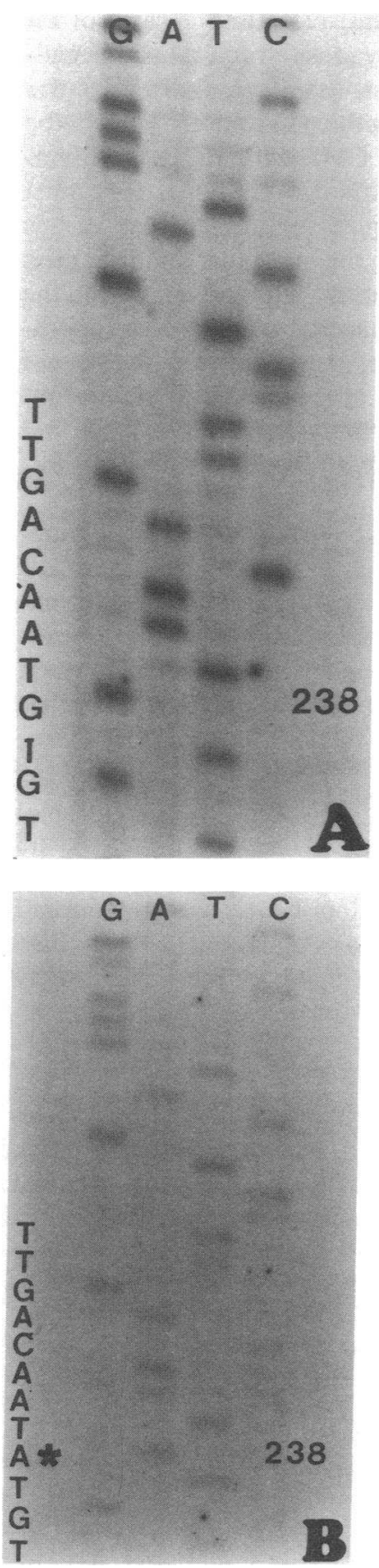

Figure 3. Sequences of a portion of exon 7 from a normal control $(A)$ and patient No. $1326(B) .{ }^{*} \mathrm{~A}$ homozygous $\mathrm{G}$ to $\mathrm{A}$ substitution at codon position 238 resulting in a change in the encoded amino acid from cysteine to tyrosine.

detailed histochemical analyses were consistent with this diagnosis.

In 6 of the cases with an identifiable mutation in the p53 gene, both a normal and a mutated allele were detected by sequencing (Figs. 2, 4-6). In 2 patients (No. 1326 and 1443) the mutation was homozygous or hemizygous (Fig. 3, Table I). Both cases had karyotypic abnormalities of $17 \mathrm{p}$ (Table I). This finding is provocative because loss of one allele coupled with mutational inactivation of the remaining allele is the hallmark of tumor suppressor genes.

We found mutations in the first exon of $N-R A S$ in only 2 of $27(7 \%)$ typical blast crisis cases and in none of 10 chronic phase cases. No mutations were found in the second exon of $N-R A S$ or in the first and second exons of $K-R A S$ and $H-R A S$ (35). Two other mutations in the first exon of $N-R A S$ were
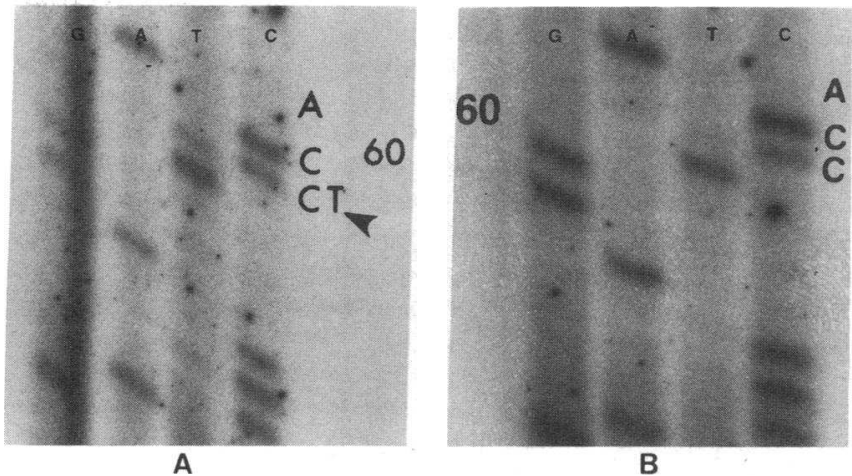

Figure 4. $(A)$ The normal sequence, and $(B)$ a mutation at codon 60 of the p53 gene in patient No. 1086. The mutation results in a CCA $\rightarrow$ TCA (Pro $\rightarrow$ Ser) conversion.

found in rare CML variants: a case of $\mathrm{Ph}^{-}$blast crisis and one of $\mathrm{Ph}^{+}$megakaryocytic blast crisis (Table I).

Transcription of the p53 gene. In an earlier study of $16 \mathrm{CML}$ blast crisis patients we reported that transcription of the $\mathrm{p} 53$ gene was frequently undetectable in leukemic leukocytes cases $(19,20)$. We have now doubled the number of CML cases studied and the results are as follows: A $2.5-2.7 \mathrm{~kb}$ p53 transcript was found in all 12 chronic phase cases analyzed and the intensity of the hybridization signal was equal to or greater than that of a concomitant HeLa cell control $(19,20)$. In 21 accelerated or blast crisis cases transcripts were undetectable in 10, increased in 1, and normal in 10 (Fig. 7). Two cases with undetectable transcripts had less than $10 \%$ blast cells. A single lymphoid blast crisis had normal transcripts. In 12 acute phase cases both RNA and DNA were available for analysis. In 4 cases both gene structure and expression were apparently normal. In 4 cases with rearranged or deleted p53 genes, transcripts were abnormal in all being absent in 3 and increased in 1 . In 4 additional cases, gene structure was normal on Southern blots, but there was no gene expression. Expression of actin mRNA was used as a control for intactness of RNA. We also studied 8 cell lines for alterations in structure and mRNA expression. While no abnormalities were detected on Southern analysis,

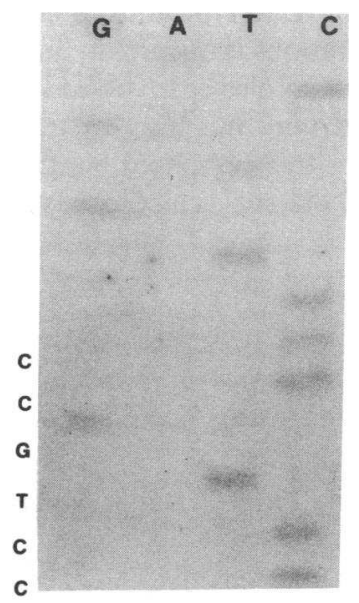

A

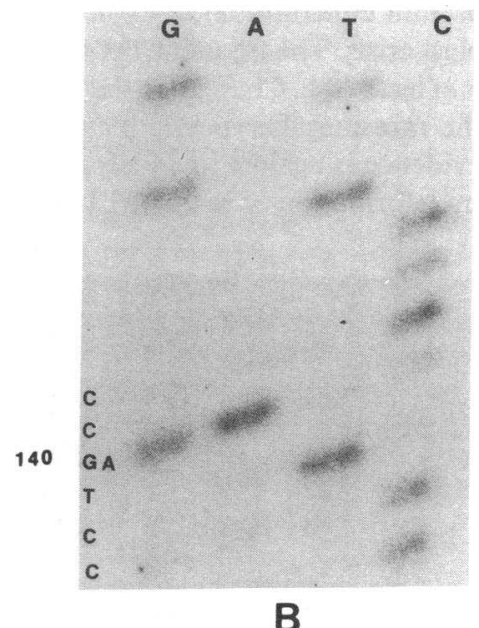

B
Figure 5. (A) The normal sequence around codon 140 of the p53 gene. $(B)$ A mutation at codon $140($ TGC $\rightarrow$ TAC) resulting in a Cys $\rightarrow$ Tyr conversion in a $\mathrm{Ph}^{1}$ negative extramedullary blast crisis (No. 972) sample. 


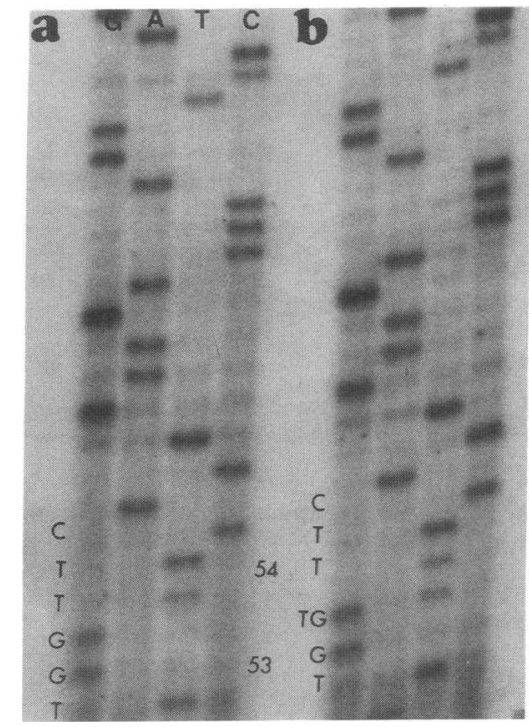

Figure 6. The normal (a) and mutated $(b)$ sequence of a segment of the $\mathrm{p} 53$ gene from patient No. 1245. The mutation at codon 53 resulted in a TGG $\rightarrow$ TGT (Trp $\rightarrow$ Cys) conversion.

the same heterogenous pattern of mRNA expression was seen. In 4 of the myeloid/undifferentiated cell lines (K562, EM2, JOSK-M, and KCL22) we could not detect p53 mRNA transcripts by Northern analysis. In 2 other myeloid cell lines (EM3 and KYO) and in a lymphoid cell line (BV173) adequate levels were seen (data not shown). In the JOSK-M cell line we have been able to demonstrate a splicing mutation in the donor splice site of exon 5 that could interfere with mRNA processing and account for the lack of p53 mRNA (36).

\section{Discussion}

CML is an excellent model for the study of molecular events involved in the initiation and progression of human malignant disease. The pathogenetic importance of $c-A B L$ early in the leukemic process is well supported by molecular and clinical analyses and by studies in mice infected by a retrovirus carrying the p210 bcr/abl gene of the $\mathrm{Ph}^{1}$ chromosome (12). Evolution of CML to a more acute phase, however, appears to involve additional molecular events. Our data and other recent reports suggest that alterations of the p53 gene may be an important concomitant of evolution of CML to typical myeloid blast crisis. The frequency of these alterations is uncertain, but is at least $30 \%$. Changes in the $\mathrm{p} 53$ gene may also be involved in the rare megakaryocytic blast crisis variant, but thus far the evidence is against its involvement in either lymphoid blastic transformation or in $\mathrm{Ph}^{+} \mathrm{ALL}$. We and Marshal et al. (22) have
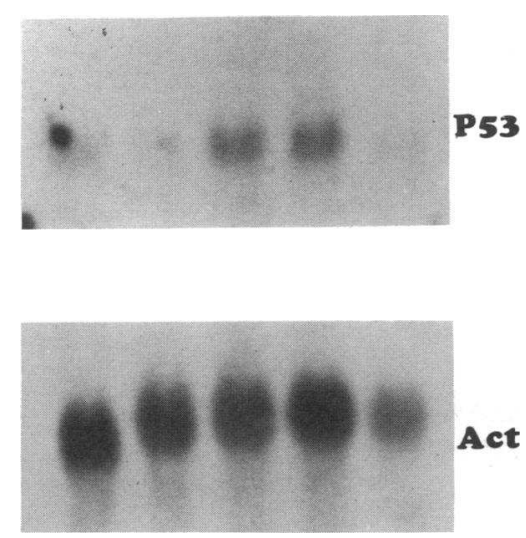

Figure 7. Northern blots of total cellular RNA probed with $\mathrm{p} 53 \mathrm{cDNA}$ (top) and $\beta$-Actin (bottom). Each lane contains DNA from leukocytes of a patient with myeloid blast crisis of CML. studied 18 cases of lymphoid blast crisis and 7 cases of $\mathrm{Ph}$ positive ALL without finding any gross structural abnormalities of the p53 gene. We suggest, therefore, that molecular events other than those involving the p53 gene are likely to be responsible for the evolution of CML variants such as lymphoid blast crisis and $\mathrm{Ph}^{+} \mathrm{ALL}$, although additional cases must be studied by complete gene sequencing to be certain of this point. It is also worth contrasting the molecular abnormalities found in acute myelogenous leukemia with those found in the myeloid blast crisis of CML: two acute leukemias that superficially look similar. In the former, mutations of $N-R A S$ genes and allelic deletion of a segment of the short arm of chromosome 11, presumably involving the Wilms' tumor locus, are frequent, whereas in myeloid blast crisis these genetic alterations are rare $(37,38)$.

A variety of data suggest that the p53 gene normally functions as an anti-oncogene. For example, it has been shown that wild type p 53 lacks the ability to induce in vitro transformation; only mutant forms have this capacity (23). On the contrary, expression of the neoplastic phenotype is inhibited when the wild type gene is transfected along with mutant $\mathrm{p} 53$ or other oncogenes (23). Abnormalities of the gene have now been identified in osteogenic sarcoma (29), colon cancer $(25,27)$, lung cancer (26), CML, breast cancer, brain tumors $(19,20,27)$, and in several cell lines (39-42). Defects in the p53 gene which lead to tumor progression may be either recessive (i.e., involve loss of both normal alleles) or may be dominant (i.e., a mutated and normal allele coexist and the former dominates) (23). Our data in the blast crisis of CML suggest that both mechanisms may operate in this disease. In $\sim 50 \%$ of myeloid blastic cases no transcripts are made, and in $\sim 15-25 \%$ of cases there is reduction to homozygosity of the p53 gene. These observations are consistent with a recessive action in which both normal alleles of the p53 gene must be lost to abrogate its tumor suppressive effect. On the other hand, some cases with gene rearrangement or with a mutation have two different alleles, suggesting that an altered gene may be dominant. Such also seems to be the case in some colon cancers $(25,27)$. However, the case for a dominant effect of a mutated p53 gene cannot be considered established until it is proven that the remaining apparently normal allele is indeed normal by all criteria.

Since alterations of the $\mathrm{p} 53$ gene are rare in chronic phase CML and are relatively common in myeloid blast crisis, a pertinent question is when the genetic alterations occur relative to disease transformation. Two cases in this study were in the accelerated phase of disease with $10 \%$ or fewer blast cells in the blood and had p 53 gene alterations. One case was informative since both the molecular and morphological analyses indicated the early emergence of a novel clone, which quickly expanded and soon led to the death of the patient. The other case had a single allele of the p53 gene during blastic crisis and both alleles during the immediately antecedent phase of disease.

We have recently studied another case of CML who had a normal p 53 gene during the chronic phase and a single mutated allele with the emergence of blast crisis. When the chronic phase was reestablished after intensive chemotherapy, two normal p53 alleles were again observed (43). These observations suggest that p 53 gene alterations occur early in the transition to a more aggressive leukemic phenotype. Although the role of p53 in carcinogenesis is still incompletely defined, we believe that the available observations warrant the hypothesis that an acquired abnormality of the p53 gene is a frequent event, and may be the principal molecular event, associated with the evo- 
lution of CML from chronic phase to myeloid blast crisis. If this hypothesis is correct, then we have an excellent model for studying the role of the p53 gene in the clonal evolution of a human malignancy.

\section{Acknowledgments}

Supported by United States Public Health Service grant CA-50275 and a gift for research to UCLA from the R. J. Reynolds Tobacco Co. We are endebted to Drs. E. Cannani, Weizman Institute, Israel; D. Durnam, Fred Hutchinson Cancer Center, Seattle, Washington; R. Gale, UCLA, Los Angeles, and R. Wassman, Genetics Institute, Pasadena, California for generously providing clinical materials; to Drs. R. Di Marco and E. W. Hays for their continuing support of these studies; and to Dr. H. Battifora, City of Hope Medical Center, Duarte, California, for his review and detailed analysis of the case of granulocytic chloroma.

\section{References}

1. Nowell, P. C., and D. A. Hungerford. 1960. A minute chromosome in human granulocytic leukemia. J. Natl. Cancer Inst. 25:85-109.

2. Rowley, J. D. 1973. A new consistent chromosomal abnormality in chronic myelogenous leukemia identified by quinacrine fluorescence and giemsa staining. Nature (Lond.). 243:290-293.

3. Bartram, C. R., A. de Klein, A. Hagemeijer, T. van Agthoven, A. Gewits van Kessel, D. Bootsma, G. Grosveld, M. A. Ferguson-Smith, T. Davies, M. Stone, N. Heisterkamp, J. R. Stephenson, and J. Groffen. 1983. Translocation of $\mathrm{c}$-abl oncogene correlates with the presence of a Philadelphia chromosome in chronic myelocytic leukemia. Nature (Lond.). 306:277-280.

4. Groffen, J., J. R. Stephenson, N. Heisterkamp, A. de Klein, C. R. Bartram, and G. Grosveld. 1984. Philadelphia chromosome breakpoints are clustered within a limited region, bcr, on chromosome 22. Cell. 36:93-99.

5. Collins, S. J., I. Kubonishi, I. Miyoshi, and M. Groudine. 1984. Altered transcription of the c-abl oncogene in K-562 and other chronic myelogenous leukemia cells. Science (Wash. DC). 225:72-74.

6. Shtivelman, E., B. Lifshitz, R. P. Gale, and E. Cannani. 1985. Fused transcript of abl and bcr genes in chronic myelogenous leukemias. Nature (Lond.). 315:550-554.

7. Ben Neriah, Y., G. Q. Daley, A. M. Mes-Masson, O. N. Witte, and D. Baltimore. 1986. The chronic myelogenous leukemia specific $\mathrm{p} 210$ protein is the product of the bcr/abl hybrid gene. Science (Wash. DC). 223:212-214.

8. Konopka, J. B., S. M. Watanabe, and O. N. Witte. 1984. Alteration of human c-abl protein in K562 leukemia cells unmasks associated tyrosine kinase activity. Cell. 37:1035-42.

9. Hermans, A., N. Heisterkamp, M. von Lindern, S. van Baal, D. Meijer, D. van der Plas, L. M. Wiedemann, G. Groffen, D. Bootsma, and G. Grosveld. 1987. Unique fusion of bcr and c-abl genes in Philadelphia chromosome positive acute lymphoblastic leukemia. Cell. 51:33-40.

10. Clark, S. S., J. McLaughlin, W. M. Crist, R. Champlin, and O. N. Witte. 1987. Unique forms of the abl tyrosine kinase distinguish $\mathrm{Ph}^{1}$-positive CML from $\mathrm{Ph}^{1}$-positive ALL. Science (Wash. DC). 235:85-88.

11. Fitzgerald, P. H., M. E. Beard, C. M. Morris, D. C. Heaton, and A. E. Reeve. 1987. $\mathrm{Ph}^{1}$ negative chronic myeloid leukemia. Br. J. Haematol. 66:311314.

12. Daley, G. Q., R. A. Van Etten, and D. Baltimore. 1990. Induction of chronic myelogenous leukemia in mice by the p210 bcr-ebl gene of the Philadelphia chromosome. Science (Wash. DC). 247:824-830.

13. McLaughlin, J., E. Chianese, and O. N. Witte. 1987. In vitro transformation of immature hematopoetic cells by the p210 BCR/ABL oncogene products of the Philadelphia chromosome. Proc. Natl. Acad. Sci. USA. 84:6558-6562.

14. Dreazen, O., E. Cannani, and R. P. Gale. 1988. Molecular biology of chronic myelogenous leukemia. Semin. Hematol. 25:35-48.

15. Shtivelman, E., R. P. Gale, O. Dreazen, A. Berribi, R. Zaizov, I. Kubonishi, I. Miyoshi, and E. Cannani. 1987. bcr-abl RNA in patients with chronic myelogenous leukemia. Blood. 69:971-973.

16. Muehleck, S. D., R. W. McKenna, D. C. Arthur, J. L. Parkin, and R. D. Brunning. 1984. Transformation of chronic myelogenous leukemia: clinical, morphologic and cytogenetic features. J. Clin. Pathol. 82:1-14.

17. Liu, E., B. Hielle, and J. M. Bishop. 1988. Transforming genes in chronic myelogenous leukemia. Proc. Natl. Acad. Sci. USA. 85:1952-1956.

18. McCarthy, D. M., J. M. Goldman, F. V. Rasool, S. V. Graham, and G. D. Birnie. 1984. Genomic alterations involving the c-myc proto oncogene during the evolution of a case of chronic granulocytic leukemia. Lancet. ii:1362-1365.
19. Ahuja, H. G., M. Bar-Eli, S. H. Advani, S. Benchimol, and M. J. Cline. 1989. Alterations in the $p 53$ gene and the clonal evolution of the blast crisis of chronic myelocytic leukemia. Proc. Natl. Acad. Sci. USA. 86:6783-6787.

20. Ahuja, H. G., M. Bar-Eli, P. Clarke, D. Snyder, S. Foreman, J. Goldman, and M. J. Cline. 1989. p53 gene alterations in blast crisis of chronic myelogenous leukemia. Cancer Cells (Cold Spring Harbor). 7:117-120.

21. Kelman, Z., M. Prokocimer, S. Peller, Y. Kahn, G. Rechavi, Y. Manor, A. Cohen, and V. Rotter. 1989. Rearrangements of the p53 gene in Philadelphia chromosome positive chronic myelocytic leukemia. Blood. 74:2318-2324.

22. Marshal, R., M. Shtalrid, M. Talpaz, H. Kantarjian, L. Smith, M. Beran, A. Cork, J. Trujillo, J. Gutterman, and A. Deisseroth. 1990. Rearrangement and expression of p53 in the chronic phase and blast crisis of chronic myelogenous leukemia. Blood. 75:180-189.

23. Finlay, C. A., P. W. Hinds, and A. J. Levine. 1989. The p53 proto-oncogene can act as a suppressor of transformation. Cell. 57:1083-1093.

24. Fleishman, E. W., E. L. Prigogina, M. A. Volkova, M. A. Frenkell, N. A Zakhartchenko, L. N. Konstantinova, G. P. Pinchkova, and S. A. Balakirev 1981. Correlations between the clinical course, characteristics of blast cells and karyotype patterns in chronic myeloid leukemia. Hum. Genet. 58:285-293.

25. Baker, S. J., E. R. Fearon, J. M. Nigro, S. R. Hamilton, A. C. Preisinger, J. M. Jessup, P. VanTuinen, D. H. Ledbetter, D. F. Barker, Y. Nakamura, R. White, and B. Vogelstein. 1989. Chromosome 17 deletions and p53 gene mutations in colorectal carcinomas. Science (Wash. DC). 244:217-220.

26. Takahashi, T., M. M. Nau, I. Chiba, M. J. Birrer, R. K. Rosenberg, M. Vinocour, M. Levitt, H. Pass, A. F. Gazdar, and J. D. Minna. 1989. p53: a frequent target for genetic abnormalities in lung cancer. Science (Wash. DC) 246:491-494.

27. Nigro, J. M., S. J. Baker, A. C. Preisinger, J. M. Jessup, R. Hostetter, K. Cleary, S. H. Bigner, N. Davidson, S. Baylin, P. Deville, T. Glover, F. S. Collins, A. Weston, R. Modali, C. C. Harris, and B. Vogelstein. 1989. Mutations in the p53 gene occur in diverse human tumor types. Nature (Lond.). 342:705-708.

28. Yokota, J., Y. Tsunetsugu-Yokota, H. Battifora, C. Lefevre, and M. J. Cline. 1986. Alterations of myc, myb, and ras-Ha proto-oncogenes in cancers are frequent and show clinical correlation. Science (Wash. DC). 231:261-265.

29. Masuda, H., C. Miller, H. P. Koeffler, H. Battifora, and M. J. Cline. 1987. Rearrangement of the p53 gene in human osteogenic sarcomas. Proc. Natl. Acad. Sci. USA. 84:7716-7719.

30. Harlow, E., N. M. Williamson, R. Ralston, D. M. Helfman, and T. E. Adams. 1985. Molecular cloning and in vitro expression of a cDNA clone for human cellular tumor antigen p53. Mol. Cell. Biol. 5:1601-1610.

31. Lamb, P., and L. Crawford. 1986. Characterization of the human p53 gene. Mol. Cell. Biol. 6:1379-1385.

32. Masuda, H., H. Battifora, J. Yokota, S. Meltzer, and M. J. Cline. 1987. Specificity of proto-oncogene amplification in human malignant diseases. $\mathrm{Mol}$. Biol. \& Med. 4:213-227.

33. Saiki, R. K., D. H. Gelfand, S. Stoffel, S. V. Scharf, R. Higuchi, G. T. Horn, K. Mullis, and H. A. Erlich. 1988. Primer directed enzymatic amplification of DNA with a thermostable DNA polymerase. Science (Wash. DC). 239:487-491.

34. Bar-Eli, M., H. G. Ahuja, N. Gonzalez-Cadavid, A. Foti, and M. J. Cline. 1989. Analysis of N-RAS exon-1 mutations in myelodysplastic syndromes by polymerase chain reaction and direct sequencing. Blood. 73:281-283.

35. Ahuja, H. G., A. Foti, M. Bar-Eli, and M. J. Cline. 1990. The pattern of mutational involvement of $R A S$ genes in human hematologic malignancies determined by DNA amplification and direct sequencing. Blood. 75:1684-1690.

36. Foti, A., M. Bar-Eli, H. G. Ahuja, and M. J. Cline. 1990. A splicing mutation accounts for the lack of p 53 mRNA expression in a CML blast crisis cell line: a novel mechanism of p53 gene inactivation. Br. J. Haematol. 76:143-145.

37. Bos, J. L., M. Verlaan-de Vries, A. J. van der Eb, J. W. G. Janssen, R Delwel, B. Lowenberg, and L. P. Colly. 1987. Mutations in N-ras predominate in acute myeloid leukemia. Blood. 69:1237-1241.

38. Ahuja, H. G., A. Foti, D. J. Zhou, and M. J. Cline 1990. Analysis of proto-oncogenes in acute myeloid leukemia: loss of heterozygosity for the HARAS gene. Blood. 1819-1822.

39. Wolf, D., and V. Rotter. 1985. Major deletions in the gene encoding the p53 tumor antigen cause lack of p53 expression in HL-60 cells. Proc. Natl. Acad. Sci. USA. 82:790-794.

40. Wolf, D., and V. Rotter. 1984. Inactivation of p 53 gene expression by an insertion of Moloney murine leukemia virus-like DNA sequences. $\mathrm{Mol}$. Cell. Biol. 7:1402-1410.

41. Mowat, M., A. Cheng, N. Kimura, A. Bernstein, and S. Benchimol. 1985. Rearrangements of the cellular p 53 gene in erythroleukemic cells transformed by Friend virus. Nature (Lond.). 314:633-636.

42. Eliyahu, D., N. Goldfinger, O. Pinhasi-Kimhi, G. Shaulski, Y. Skurnik, N. Aria, V. Rotter, and M. Oren. 1988. Meth A fibrosarcoma cells express two transforming mutant p53 species. Oncogene. 3:313-321.

43. Foti, A., H. G. Ahuja, S. L. Allen, P. Koduru, M. W. Schuster, P. Schulman, M. Bar-Eli, and M. J. Cline. 1991. Correlation between molecular and clinical events in the evolution of CML to blast crisis. Blood. In press. 